J. Lake Sci. (湖泊科学) , 2017, 29(4): 827-835

DOI 10. 18307/2017. 0406

(C) 2017 by Journal of Lake Sciences

\title{
城镇化下河流水质变化及其与景观格局关系分析一一以太湖流域苏 州市为例
}

\author{
杨 洁 ${ }^{1}$, 许有鹏 ${ }^{1 * *}$, 高 斌 ${ }^{1}$, 王跃峰 ${ }^{1}$, 徐 羽 $^{1}$,马 倩 ${ }^{2}$ \\ (1: 南京大学地理与海洋科学学院, 南京 210023) \\ (2: 江苏省水文水资源勘测局,南京 210008)
}

\begin{abstract}
摘 要: 以河流近域景观格局与水环境质量间的关系为研究对象, 基于 2001 年及 2010 年两期土地利用类型以及 7 条典 型河流的溶解氧、氨氮、高锰酸盐指数、总磷、总氮 5 项水质指标, 分析城镇化下苏州市河流水质与景观格局之间的关系及 其变化规律. 结果表明: (1) 苏州市河流水质状况总体较差, 但呈现一定的好转趋势. (2) 河流水质受到城镇用地、旱地及 水田的综合影响,并表现出尺度效应. 其中城镇用地与旱地对河流水质恶化具有明显的作用,水田则反之. 2001-2010 年 城镇用地及水田对水质的影响程度有所减弱,旱地则增强. (3) 蔓延度指数、最大面积斑块比例对河流水质呈现负相关, 斑块数量、斑块密度、香农均匀度指数、香农多样性指数则与水质呈现正相关. 景观格局对于水质的影响在大范围缓冲区 更为显著. 研究结果可为苏州水环境管理及太湖流域城市空间开发提供一定的参考依据.
\end{abstract}

关键词: 水质变化;土地利用;景观空间特征;城镇化;苏州市;太湖流域

\section{River water quality change and its relationship with landscape pattern under the urbaniza- tion: A case study of Suzhou City in Taihu Basin}

\author{
YANG Jie $^{1}$, XU Youpeng ${ }^{1 * *}$, GAO Bin ${ }^{1}$, WANG Yuefeng ${ }^{1}$, XU Yu ${ }^{1} \&$ MA Qian ${ }^{2}$ \\ (1: School of Geographic and Oceanographic Sciences Institute, Nanjing University, Nanjing 210023, P.R.China) \\ (2: Jiangsu Province Hydrology and Water Resources Investigation Bureau, Nanjing 210008, P.R.China)
}

\begin{abstract}
Based on land use data and water quality data of seven typical rivers of 2001 and 2010, the relationship between landscape pattern and water quality indicators and its change characteristics in Suzhou City under the urbanization were analyzed. The monitoring data was consisted of five water quality indicators including dissolved oxygen, ammonia, potassium permanganate index, total phosphorus and total nitrogen. The results were listed as follows. The water quality of Suzhou City was general poor, although showed a trend of improvement. River water quality suffered the comprehensive influence of urban land, dry land and paddy field in research area. The influence varies among scales. Meanwhile, urban land and the dry land had obvious effect on the deterioration of river water quality. The correlation between urban land area and paddy field area and water quality indexes abated in small scales in 2001-2010. However, the impact of dry land on water quality was greatly increased. What's more, water quality was negatively correlated to contagion index and the largest patch index and positively correlated to number of patches, patch density, Shannon's evenness index and Shannon's diversity index. The effects of landscape pattern in a wide range of buffer on water quality was more significant. The research results provided certain reference basis to Suzhou water environment management and urban space development of the Taihu Basin.
\end{abstract}

Keywords: Water quality change; land use; landscape spatial characteristics; urbanization; Suzhou City; Taihu Basin

城镇化引起了土地利用结构的巨大改变, 并对区域气候、土壤及水体产生深刻影响 ${ }^{[1]}$. 在城镇化过程

* 国家重点研发计划专项(2016YFC0401502)、国家自然科学基金项目(41371046,41401035)、江苏水利科技基金项 目 (2015003) 和水利部水利公益专项 (201201072,201501041) 联合资助. 2016-07-25 收稿; 2016-10-11 收修改 稿. 杨洁(1992 ) ,女, 硕士研究生;E-mail :yueyingliuyun@126.com.

** 通信作者;E-mail:xuyp305@163.com. 
中, 随着经济发展和人口增长, 城镇用地急速扩张, 强烈影响区域水循环过程 ${ }^{[2]}$, 并加快区域河网水系的衰 减程度, 河流连通受阻, 打破原有河网的水生态平衡,引发一系列水环境问题 ${ }^{[3]}$.

近年来, 景观格局与河流水质之间的关系成为国内外研究的热点 ${ }^{[4-5]}$. 大量研究表明景观格局与区域水 环境之间存在明显的相互作用 ${ }^{[4-15]}$. 研究的方向主要包括两方面: 以景观格局的组成属性为基础, 即土地利 用类型百分比与河流水质之间的关系 ${ }^{[6-10]}$; 以景观格局的空间结构为基础, 即通过景观指数探究不同土地利 用类型的空间布局与水质之间的关系 ${ }^{[4-5,11-12]}$. 在时间尺度上, 主要基于多年水质监测数据以及景观格局的 变化数据分析二者的相关规律; 研究的空间尺度主要包括流域 ${ }^{[6-8]}$ 、子流域 ${ }^{[9]}$ 及缓冲区 [ $^{[4-5,10-11]}$ 等几种类型. 目前, 景观格局与水质关系研究常用的方法包括相关分析、多元回归分析、主成分分析、方差分析及模型分 析等 ${ }^{[4-5,8,11,13]}$. 但在不同地区, 关于不同景观指数和水质指标相关关系的研究仍存在不确定性, 需要在更广 泛的地区针对相应问题开展研究, 以期进一步理解二者之间关系机制.

太湖是国家 “三河三湖” 水污染防治的重点湖泊之一, 更是江苏省水污染防治的重点 ${ }^{[5]}$. 环太湖的苏锡 常地区在我国区域经济发展中起着举足轻重的作用 ${ }^{[16]}$. 然而, 城镇化、工业化的快速推进导致区域经济发 展和水环境保护的矛盾十分突出. 在此背景下, 选取太湖流域腹部地区的苏州市为研究区, 探讨城镇化下景 观格局与水质的关系及其时空变化趋势具有很强的现实意义. 本研究旨在揭示不同土地利用类型对城市河 道污染的影响程度, 水质与景观格局变化的多尺度响应关系及其变化特征, 以期为苏州市合理调整土地利 用结构,改善水环境质量提供理论参考, 同时也为太湖流域空间开发提供科学依据.

\section{1 研究区概况与数据基础}

\section{1 研究区概况}

苏州市地处长江三角洲中部、太湖流域东北部, 位于 $30^{\circ} 47^{\prime} \sim 32^{\circ} 02^{\prime} \mathrm{N}, 119^{\circ} 55^{\prime} \sim 121^{\circ} 20^{\prime} \mathrm{E}$ 之间, 东邻上 海, 南连浙江, 西傍太湖, 北枕长江. 属于亚热带湿润性季风海洋性气候, 雨量充沛. 全市总面积约 $8488 \mathrm{~km}^{2}$, 地势低平, 地形以平原为主, 平原占总面积的 55\%, 拥有各级河道 2 万多条, 大小湖泊 300 个. 2014 年实现地 区生产总值 13760.89 亿元, 居全国第 7 位, 年末常住人口 1060.40 万人 ${ }^{[17]}$.

\section{2 数据基础}

本研究涉及资料包括苏州市土地利用数据及水质数据. 土地利用数据包括 2001 年 7 月 24 日及 2010 年 5 月 24 日两期, 由 Landsat TM、ETM 影像通过监督分类解译所得, 分类系统参考中国土地资源分类系统, 并 根据研究区土地覆被类型特点及研究目的划分为旱地、城镇用地、水田、水域和林地 5 大类别. 并结合实际 考查数据、地形图及高分辩遥感影像对分类结果进行精度验证, 2001 年总体分类精度 $87.62 \%$, Kappa 系数 $0.85 ; 2010$ 年总体分类精度 $85.69 \%$, Kappa 系数 0.81 . 水质资料为苏州市主要骨干河道上的 21 个水质监测 断面的月实测资料 (图 1). 根据太湖流域水质监测站点的水质数据, 选取对河流水环境质量影响较为突出 的常规检测指标溶解氧 $(\mathrm{DO})$ 、氨氮 $\left(\mathrm{NH}_{3}-\mathrm{N}\right)$ 、高锰酸盐指数 $\left(\mathrm{COD}_{\mathrm{Mn}}\right)$ 、总磷 $(\mathrm{TP})$ 、总氮 $(\mathrm{TN})$. 其中 11 个断 面水质资料监测年限为 2004-2014 年, 其余为 2001-2014 年, TN、TP 指标的监测则从 2002 年开始. 结合水 质断面监测资料年限及其分布情况 (图 1), 对苏州市水质监测断面数据进行篎选, 选出具有较长观测时间的 王市望虞河大桥等 10 个断面, 分别位于望虞河、常吘河、元和塘、杨林塘、娄江、胥江、太浦河等 7 条骨干 河道.

\section{2 研究方法}

平原水网地区河流呈往复流态且上下游关系不明显, 同一断面水质可能受多个方向来水影响, 因而采 用以水质监测断面为中心的圆形缓冲区作为水文单元 ${ }^{[18]}$. 研究中缓冲区单元尺度主要依据国外区域水环 境与景观格局关系的尺度效应研究确定, 大多以 $100 \mathrm{~m}$ 作为最小空间单元 (即河岸带尺度), 最大空间单元 尺度则一般为 1000 $2000 \mathrm{~m}^{[18-19]}$. 结合研究区范围, 选择 $100 、 300 、 500 、 700 、 1000 \mathrm{~m}$ 共 5 个尺度, 并以水质监 测断面为中心,生成 2001 年及 2010 年两期共 100 个圆形缓冲区.

在各缓冲区内, 使用 Fragstats 3.3 计算景观水平和类型水平上的景观指数, 包括各用地类型所占面积比 例以及最大斑块所占面积比例 ( LPI) 、斑块数量 $(\mathrm{NP})$ 、斑块密度 $(\mathrm{PD})$ 、香农多样性指数( SHDI)、香农均匀 


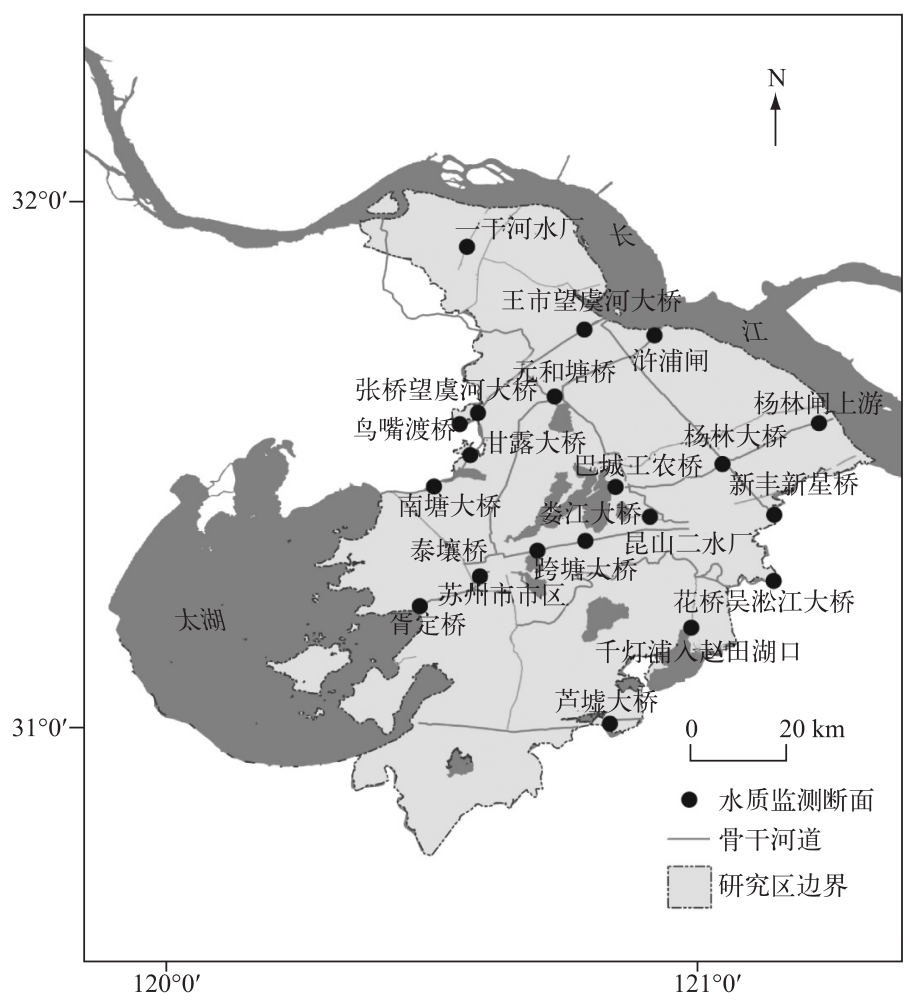

图 1 苏州市主要骨干河道及水质监测断面分布

Fig.1 Distribution of main rivers and water quality monitoring sites in Suzhou City

度指数 (SHEI) 和蔓延度指数 ( CONTAG) 等 6 个景观指数. LPI 反映了景观中最大斑块面积占整个景观面积 的比例. NP 反映景观中斑块的总数. PD 表征单位面积的斑块数. SHDI 的大小反映景观类型的多少和各景 观类型所占比例的变化. SHEI 用于描述景观中不同斑块类型分配的均匀程度. CONTAG 是用于测量景观中 不同斑块类型的聚集程度 ${ }^{[16]}$. CONTAG 和 LPI 可用于表征景观斑块聚集程度及优势景观类型, 而 PD、NP 及 SHDI 都是景观破碎程度的表征 ${ }^{[20]}$, 可反映景观中各斑块类型的丰富度和复杂性,SHEI 可以反映景观的多 样性. 这几项指标分别从景观要素及总体特征来对缓冲区内的景观格局进行表征.

\section{3 结果与分析}

\section{1 河流水质总体变化}

选取对河流水环境质量影响较为突出的常规检测指标 $\mathrm{DO} 、 \mathrm{TN} 、 \mathrm{NH}_{3}-\mathrm{N} 、 \mathrm{TP}$ 和 $\mathrm{COD}_{\mathrm{Mn}}$, 采用单因子评价 法 ${ }^{[21]}$ 来量化河流水质情况 (图 2). 根据国家《地表水环境质量标准》(GB 3838-2002),2004-2014 年苏州 市 $\mathrm{I} \sim$ 劣 $\mathrm{V}$ 类水质断面比重总体呈现减小趋势, 但在 2014 年仍达到 $52.38 \%$. 其中 $\mathrm{TN} 、 \mathrm{NH}_{3}-\mathrm{N}$ 超标最为严 重, 是主要污染物. 除工业点源污染外, 其来源主要是水产养殖业、农业种植业和畜禽养殖业等农业面源污 染的排放 ${ }^{[22]}$, 以及城市降雨径流所带来的氮营养盐 ${ }^{[23-24]}$. 研究区水质污染表现出一定的改善趋势, 但总体 仍然严峻. 究其原因,一方面, 2001-2010 年各水质监测断面缓冲区内水域面积总体呈现增长趋势, 表明随 着保护意识的提高以及相关整治措施的施行, 城市河流水系有所恢复, 并对提高城市水环境质量具有一定 效果;另一方面则得益于“引江济太”工程等 ${ }^{[25]}$ 相关工程性措施的实施,使得水体流通性增强.

\section{2 土地利用对主要河道水质的影响分析}

3.2.1 缓冲区土地利用结构变化 缓冲区土地利用结构分析 (图 3) 显示, 各尺度缓冲区内城镇用地及耕地 (水田、旱地) 为主要地类, 占比总体超过 $80 \% .2001$ 年各缓冲区内地类比重由大到小分别是: 城镇用地、水 


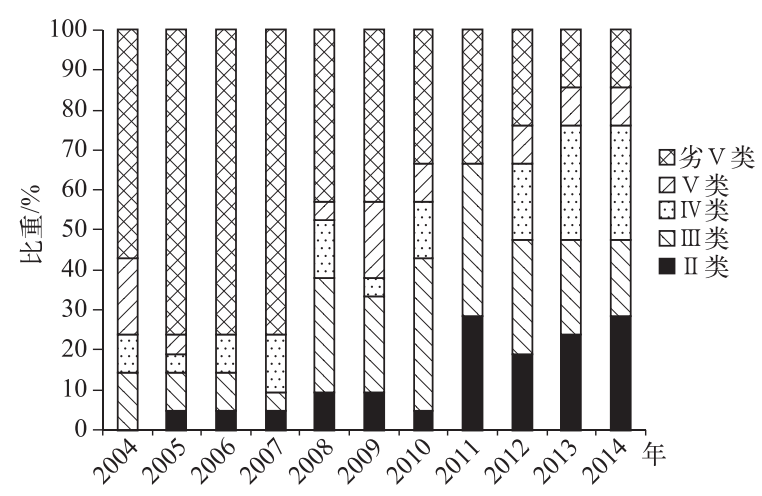

图 2 不同水质等级的监测断面数量比重

Fig. 2 The ratios of monitoring sites presenting different water quality grades

田、水域、旱地、林地. 2010 年各缓冲区尺度仍以城镇用地为主, 林地面积最小, 不同的是旱地面积显著增加, 水域面积有所恢复,水田面积快速下降.

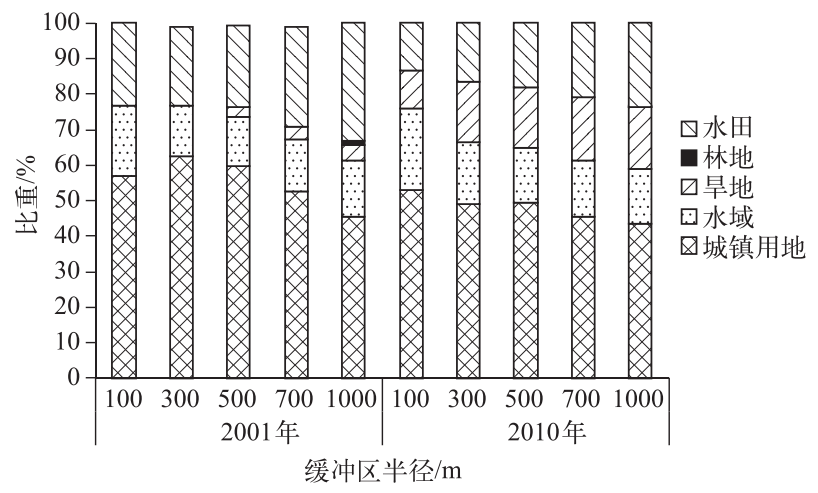

图 3 缓冲区土地利用结构

Fig.3 Land-use composition in buffer zone

3.2.2 土地利用类型对水质的影响 由于 2001 年各监测断面尚未开展 TP、TN 监测, 通过对临近两年的 TP、 $\mathrm{TN}$ 数据变化趋势进行分析, 发现数据年际变化较小, 且按照水环境标准均属于同一类别, 同时土地利用年 际间变化程度有限,因此用 2002 年的 TP、TN 数据替代 2001 年. 采用 2001 年及 2010 年 5 个缓冲区尺度内 各土地利用类型面积比重及水质指标数据, 研究土地利用类型与河流水质的响应关系及其变化情况 (表 1).

从相关分析结果 (表 1 ) 表明, 不同时期各土地利用类型面积比例与各水质污染指标之间关系各异. 2001 年, 城镇用地与 $\mathrm{DO} 、 \mathrm{COD}_{\mathrm{Mn}} 、 \mathrm{NH}_{3}-\mathrm{N} 、 \mathrm{TP}$ 及 $\mathrm{TN}$ 自 $500 \mathrm{~m}$ 缓冲区范围开始呈现显著相关 $(P<0.05$, 下同 $)$, 其中与 $\mathrm{DO}$ 呈负相关. 水田与 $\mathrm{DO}$ 在 100 及 $300 \mathrm{~m}$ 缓冲区呈显著正相关, 与 $\mathrm{COD}_{\mathrm{Mn}}$ 在 $100 \mathrm{~m}$ 缓冲区呈显著负 相关, 与 $\mathrm{TN}$ 在 $500 、 700 、 1000 \mathrm{~m}$ 缓冲区均呈现显著负相关, 与 $\mathrm{DO} 、 \mathrm{COD}_{\mathrm{Mn}} 、 \mathrm{TP} 、 \mathrm{NH}_{3}-\mathrm{N}$ 在 $500 、 700 、 1000 \mathrm{~m}$ 缓 冲区显著性均更强 $(P<0.01)$. 旱地、林地与各水质指标并没有较为显著的相关关系. 总体上, 城镇用地及水 田是影响水质的主要地类,且在 $500 \sim 1000 \mathrm{~m}$ 缓冲区范围影响较显著.

2010 年, 城镇用地、水田及旱地是水质的主要影响地类. 城镇用地与 $\mathrm{COD}_{\mathrm{Mn}}$ 在 $700 、 1000 \mathrm{~m}$ 缓冲区范围内 呈显著正相关, 与 $\mathrm{DO}$ 在 $1000 \mathrm{~m}$ 缓冲区呈显著负相关 $(P<0.01)$. 水田在 $500 \mathrm{~m}$ 与 DO 呈显著正相关、与 $\mathrm{COD}_{\mathrm{Mn}}$ 呈显著负相关, 在 $700 、 1000 \mathrm{~m}$ 缓冲区范围内显著性均更强 $(P<0.01)$; 与 $\mathrm{TP} 、 \mathrm{NH}_{3}-\mathrm{N}$ 在 $700 \mathrm{~m}$ 缓冲区呈显著负 相关. 旱地与 DO 在 700 和 $1000 \mathrm{~m}$ 缓冲区均呈显著负相关, 在 300 及 $500 \mathrm{~m}$ 缓冲区相关性更强 $(P<0.01)$; 与 $\mathrm{COD}_{\mathrm{Mn}}$ 自 $300 \mathrm{~m}$ 缓冲区呈显著正相关, 与 $\mathrm{TP} 、 \mathrm{NH}_{3}-\mathrm{N}$ 在 $300 \sim 1000 \mathrm{~m}$ 的多个尺度上呈现显著正相关. 
综合两期分析结果, 苏州市河流水质受到多种土地利用类型的综合影响. 不同土地利用类型对各水质 指标的影响程度及范围不同, 且具有一定的空间尺度性特征. 随着缓冲区尺度的增加, 各地类与水质指标的 相关性总体呈增强趋势. 2001 年, 城镇用地、水田的影响分别在 $700 、 1000 \mathrm{~m}$ 缓冲半径作用区达到最大. 2010 年, 城镇用地、旱地、水田的影响则分别在 $1000 、 1000 、 700 \mathrm{~m}$ 缓冲半径作用区达到最大. 总体上, 各地类对水 质的影响范围由 2001 年集中在 $500 \sim 1000 \mathrm{~m}$ 缓冲区之间变化为 2010 年的 $700 \sim 1000 \mathrm{~m}$ 缓冲区之间. 城镇用 地及水田对水质的影响变化总体表现为同尺度上影响减弱, 以及呈现显著影响的起始尺度增大; 旱地面积 对水质指标的影响则有增强的趋势. 这与各地类面积比重的变化趋势相符. 此外, 相关研究表明河流近域附 近林地增加可以通过植物吸收、土壤滞留等作用减少和截留部分污染物 ${ }^{[26]}$. 而研究区中林地比重较小, 很 难发挥大的水质改善作用,与各水质指标未呈现较为明显的关系.

\section{表 1 土地利用类型与水质指标相关分析}

Tab. 1 Correlation analysis between proportion of land use type and water quality indicators

\begin{tabular}{|c|c|c|c|c|c|c|c|c|}
\hline \multirow{2}{*}{$\begin{array}{l}\text { 水质 } \\
\text { 指标 }\end{array}$} & \multirow{2}{*}{$\begin{array}{l}\text { 缓冲区 } \\
\text { 半径/m }\end{array}$} & \multicolumn{4}{|c|}{2001 年 } & \multicolumn{3}{|c|}{2010 年 } \\
\hline & & 城镇用地 & 旱地 & 林地 & 水田 & 城镇用地 & 旱地 & 水田 \\
\hline \multirow[t]{5}{*}{ DO } & 100 & -0.57 & - & - & $0.73^{*}$ & 0.24 & -0.36 & 0.41 \\
\hline & 300 & -0.55 & -0.41 & 0.17 & $0.67^{*}$ & -0.35 & $-0.86^{* *}$ & 0.50 \\
\hline & 500 & $-0.69^{*}$ & -0.44 & 0.49 & $0.85^{* *}$ & -0.46 & $-0.86^{* *}$ & $0.71^{*}$ \\
\hline & 700 & $-0.73^{*}$ & -0.46 & 0.49 & $0.87^{\text {** }}$ & -0.61 & $-0.72 *$ & $0.82^{* * *}$ \\
\hline & 1000 & $-0.71^{*}$ & -0.44 & 0.49 & $0.88^{* *}$ & $-0.77^{* *}$ & $-0.65^{*}$ & $0.79^{* *}$ \\
\hline \multirow[t]{5}{*}{$\mathrm{NH}_{3}-\mathrm{N}$} & 100 & 0.53 & - & - & -0.58 & -0.52 & 0.11 & -0.21 \\
\hline & 300 & 0.47 & 0.06 & -0.17 & -0.59 & 0.08 & $0.66^{*}$ & -0.42 \\
\hline & 500 & $0.67^{*}$ & 0.31 & -0.34 & $-0.77^{* *}$ & 0.35 & 0.61 & -0.46 \\
\hline & 700 & $0.71 *$ & 0.32 & -0.34 & $-0.74^{*}$ & 0.48 & $0.64^{*}$ & $-0.67^{*}$ \\
\hline & 1000 & $0.70^{*}$ & 0.31 & -0.34 & $-0.77^{* *}$ & 0.54 & $0.66^{*}$ & -0.62 \\
\hline \multirow[t]{5}{*}{$\mathrm{TP}$} & 100 & 0.56 & - & - & -0.62 & -0.29 & 0.54 & -0.25 \\
\hline & 300 & 0.51 & 0.06 & -0.17 & -0.63 & 0.13 & $0.66^{*}$ & -0.31 \\
\hline & 500 & $0.67^{*}$ & 0.32 & -0.42 & $-0.78^{* * *}$ & 0.26 & 0.60 & -0.36 \\
\hline & 700 & $0.73^{*}$ & 0.31 & -0.42 & $-0.77^{* *}$ & 0.35 & 0.61 & $-0.69^{*}$ \\
\hline & 1000 & $0.72 *$ & 0.32 & -0.42 & $-0.80^{* *}$ & 0.32 & $0.76^{*}$ & -0.62 \\
\hline \multirow[t]{5}{*}{$\mathrm{TN}$} & 100 & 0.60 & - & - & -0.55 & -0.67 & 0.13 & -0.08 \\
\hline & 300 & 0.53 & -0.06 & -0.29 & -0.56 & -0.13 & 0.55 & -0.30 \\
\hline & 500 & $0.72 *$ & 0.20 & -0.51 & $-0.74^{*}$ & 0.18 & 0.46 & -0.26 \\
\hline & 700 & $0.72 *$ & 0.25 & -0.51 & $-0.69^{*}$ & 0.38 & 0.44 & -0.49 \\
\hline & 1000 & $0.70^{*}$ & 0.20 & -0.51 & $-0.68^{*}$ & 0.44 & 0.47 & -0.47 \\
\hline \multirow[t]{5}{*}{$\mathrm{COD}_{\mathrm{Mn}}$} & 100 & 0.51 & - & - & $-0.66^{*}$ & -0.20 & 0.38 & -0.34 \\
\hline & 300 & 0.51 & 0.41 & -0.17 & -0.60 & 0.39 & $0.68^{*}$ & -0.44 \\
\hline & 500 & $0.66^{*}$ & 0.50 & -0.49 & $-0.79^{* *}$ & 0.58 & $0.69^{*}$ & $-0.64 *$ \\
\hline & 700 & $0.67^{*}$ & 0.53 & -0.49 & $-0.80^{* *}$ & $0.66^{*}$ & $0.66^{*}$ & $-0.82^{* * *}$ \\
\hline & 1000 & 0.64 * & 0.50 & -0.49 & $-0.82 * *$ & $0.75^{*}$ & $0.75^{*}$ & $-0.86^{* *}$ \\
\hline
\end{tabular}

**表示在 0.01 水平上显著相关, *表示在 0.05 水平上显著相关.

\section{3 景观格局对主要河道水质的影响分析}

3.3.1 缓冲区景观格局特征变化 两时相各缓冲区尺度景观格局存在时空变化特征 (表 2). 时间上, LPI 及 CONTAG 呈下降趋势, NP、PD、SHEI、SHDI 均呈现增加趋势, 即缓冲区内的景观格局呈现破碎度增大, 多样 性增加的趋势. 空间上, 随着缓冲区距离增加, LPI 和 PD 均呈现下降趋势, NP、SHEI、SHDI 则呈增加趋势, 其 中 SHEI、SHDI 的最大值均出现在 $1000 \mathrm{~m}$ 缓冲区. CONTAG 在 2001 年随缓冲区半径增大呈上升的趋势, 2010 年则变化不大. 
表 2 缓冲区景观格局

Tab.2 Landscape pattern in buffer zone

\begin{tabular}{|c|c|c|c|c|c|c|c|c|c|c|c|c|}
\hline \multirow{2}{*}{$\begin{array}{l}\text { 缓冲区 } \\
\text { 半径 } / \mathrm{m}\end{array}$} & \multicolumn{2}{|c|}{ LPI } & \multicolumn{2}{|c|}{ NP } & \multicolumn{2}{|c|}{ PD } & \multicolumn{2}{|c|}{ CONTAG } & \multicolumn{2}{|c|}{ SHEI } & \multicolumn{2}{|c|}{ SHDI } \\
\hline & 2001 年 & 2010 年 & 2001 年 & 2010 年 & 2001 年 & 2010 年 & 2001 年 & 2010 年 & 2001 年 & 2010 年 & 2001 年 & 2010 年 \\
\hline 100 & 83.85 & 62.43 & 1.80 & 3.90 & 57.48 & 117.12 & 19.30 & 34.98 & 0.35 & 0.65 & 0.28 & 0.72 \\
\hline 300 & 86.28 & 47.29 & 2.80 & 17.30 & 10.00 & 61.47 & 51.41 & 35.99 & 0.36 & 0.73 & 0.36 & 0.96 \\
\hline 500 & 78.49 & 50.38 & 6.70 & 36.40 & 8.60 & 46.40 & 64.60 & 35.49 & 0.48 & 0.75 & 0.53 & 1.00 \\
\hline 700 & 70.10 & 49.31 & 10.30 & 68.40 & 6.70 & 44.49 & 56.86 & 35.00 & 0.61 & 0.77 & 0.69 & 1.05 \\
\hline 1000 & 62.41 & 45.75 & 13.60 & 133.80 & 4.36 & 42.56 & 57.40 & 33.48 & 0.61 & 0.80 & 0.74 & 1.08 \\
\hline
\end{tabular}

3.3.2 景观格局对水质的影响 两期景观指数与水质指标相关分析结果显示, 景观格局对水质的影响在大范 围缓冲区更为显著 (表 3). 因 $1000 \mathrm{~m}$ 尺度缓冲区内大部分景观指数与水质指标之间相关关系显著, 因此对 其进行着重分析. 2001 年, $\mathrm{NP} 、 \mathrm{PD}$ 与 $\mathrm{NH}_{3}-\mathrm{N} 、 \mathrm{TP} 、 \mathrm{COD}_{\mathrm{Mn}}$ 均呈显著负相关, 与 $\mathrm{TN}$ 也呈现显著负相关 $(P<$ 0.01). CONTAG 与 $\mathrm{NH}_{3}-\mathrm{N} 、 \mathrm{TN} 、 \mathrm{TP}$ 均呈显著正相关, $\mathrm{SHEI}$ 与 $\mathrm{NH}_{3}-\mathrm{N} 、 \mathrm{TN}$ 均呈显著负相关, SHDI 与 TN 也呈 较强负相关关系. 2010 年, $\mathrm{LPI}$ 与 DO 呈显著负相关, 与 $\mathrm{NH}_{3}-\mathrm{N}$ 、TN 均呈显著正相关, 与 $\mathrm{COD}_{\mathrm{Mn}}$ 也存在显著正 相关. CONTAG 与 $\mathrm{NH}_{3}-\mathrm{N} 、 \mathrm{TN} 、 \mathrm{TP}$ 等污染指标均呈显著正相关. SHEI 与水质指标存在显著的相关关系, 其中 与 $\mathrm{DO}$ 呈显著正相关, 与 $\mathrm{TP} 、 \mathrm{COD}_{\mathrm{Mn}}$ 均呈显著负相关, 与 $\mathrm{NH}_{3}-\mathrm{N} 、 \mathrm{TN}$ 的负相关更为显著 $(P<0.01)$.

综合两期分析结果, LPI、CONTAG 及 SHEI 与水质指标的相关性有所增强, NP、PD 则减弱. $\mathrm{NH}_{3}-\mathrm{N} 、 \mathrm{TN}$ 、 TP 始终与 CONTAG 呈正相关, SHEI 则与 $\mathrm{NH}_{3}-\mathrm{N}$ 、TN 均呈负相关.

表 3 景观指数与水质指标的相关分析 $(1000 \mathrm{~m})$

Tab.3 Correlation analysis between landscape pattern and water quality indicators $(1000 \mathrm{~m})$

\begin{tabular}{|c|c|c|c|c|c|c|c|}
\hline 时间 & 水质指标 & LPI & NP & PD & CONTAG & SHEI & SHDI \\
\hline \multirow[t]{5}{*}{2001 年 } & DO & -0.19 & 0.61 & 0.61 & -0.47 & 0.50 & 0.32 \\
\hline & $\mathrm{NH}_{3}-\mathrm{N}$ & 0.41 & $-0.73^{*}$ & $-0.73^{*}$ & $0.76^{*}$ & $-0.75^{*}$ & -0.52 \\
\hline & $\mathrm{TP}$ & 0.29 & $-0.67^{*}$ & $-0.67^{*}$ & $0.64^{*}$ & -0.61 & -0.39 \\
\hline & $\mathrm{TN}$ & 0.39 & $-0.92^{* *}$ & $-0.92^{* *}$ & 0.71 * & $-0.70^{*}$ & -0.65 * \\
\hline & $\mathrm{COD}_{\mathrm{Mn}}$ & 0.18 & $-0.65^{*}$ & $-0.65^{*}$ & 0.46 & -0.49 & -0.33 \\
\hline \multirow[t]{5}{*}{2010 年 } & DO & $-0.75^{*}$ & -0.09 & -0.09 & -0.47 & $0.64^{*}$ & 0.57 \\
\hline & $\mathrm{NH}_{3}-\mathrm{N}$ & $0.73^{*}$ & 0.21 & 0.21 & $0.70^{*}$ & $-0.86^{\text {*** }}$ & -0.58 \\
\hline & TP & 0.60 & 0.10 & 0.10 & 0.73 * & $-0.75^{*}$ & -0.32 \\
\hline & $\mathrm{TN}$ & $0.69^{*}$ & 0.10 & 0.10 & $0.75^{*}$ & $-0.88^{\text {*** }}$ & -0.56 \\
\hline & $\mathrm{COD}_{\mathrm{Mn}}$ & $0.78^{* *}$ & 0.25 & 0.25 & 0.40 & $-0.63 *$ & -0.56 \\
\hline
\end{tabular}

**表示在 0.01 水平上显著相关, * 表示在 0.05 水平上显著相关.

\section{4 讨论}

\section{1 土地利用类型与河流水质}

研究区城镇用地与 $\mathrm{COD}_{\mathrm{Mn}} 、 \mathrm{TN} 、 \mathrm{NH}_{3}-\mathrm{N} 、 \mathrm{TP}$ 等污染指标呈正相关, 是水质的重要影响因子, 对其具有负效 应, 与相关研究结论一致 ${ }^{[1,4,11]}$. 这可以理解为城镇化过程中不透水区和建设用地面积的增加导致污染物随 着暴雨径流的冲刷进人水体, 造成水体中营养盐及有机物含量增加 ${ }^{[4]}$, 水质下降. 此外, 城市地区对应的工 业和商业活动也会造成工业点源污染及城镇面源污染. 同时, 城镇用地对水质的影响随缓冲区距离增加而 增大, 这与污染物排放量随缓冲区范围增加产生的累积具有重要联系. 根据苏州市 2011 年污染物普查数 据, 在 10 个监测断面 $300 、 700 、 1000 \mathrm{~m}$ 缓冲区内分别有 $1 、 2 、 4$ 个排污口, 年 $\mathrm{COD}_{\mathrm{Mn}}$ 人河排放量随缓冲区距离 增加而增大,共为 $2181.03 \mathrm{t}$, 分别是 $\mathrm{TN} 、 \mathrm{NH}_{3}-\mathrm{N}$ 和 $\mathrm{TP}$ 人河量的 3.39、10.00 和 1016.59 倍.

除建设用地外, 水田及旱地也是水质的重要影响因子. 其中, 旱地对于 $\mathrm{COD}_{\mathrm{Mn}} 、 \mathrm{TN} 、 \mathrm{NH}_{3}-\mathrm{N}$ 等污染指标在 
部分尺度上呈较强的正相关, 对水质具有负效应, 水田反之. Jung 等 ${ }^{[27]}$ 的研究也发现稻田及其他农业用地 面积比例与 BOD、TN、TP、大肠杆菌等污染指标存在负相关关系, 与本研究结果较为一致. 目前的研究多数 采用耕地作为因子分析其对水质的影响, 并发现耕地与 $\mathrm{TN} 、 \mathrm{TP}$ 呈现负相关 ${ }^{[1,28]}$, 但与 $\mathrm{DO}$ 及 $\mathrm{COD}_{\mathrm{Mn}}^{[14,28]}$ 的关 系在不同区域的研究结果有所差异. 这也表明水田和旱地对于水质指标影响的方式和程度不同,则其比例 组合不同会使耕地与水质的关系具有区域变化性. 究其原因,一方面可能是由于水田作为植被或湿地系统 对污染物具有一定的吸附、吸收、滞留作用 ${ }^{[29]}$. 另一方面是由于水田对污染物的产生与排放贡献不及城镇 用地和旱地, 对河流水质的负面影响较弱 ${ }^{[5]}$. 建设用地、旱地与水田作为主要的污染输出用地类型, 对河流 水体污染的影响呈现 “此消彼长” 的强弱关系 ${ }^{[5]}$. 因此, 合理规划河岸耕地类型比重、控制城镇用地的发展, 对于苏州城市河流水质的改善十分必要.

总体来看,城镇化区域河流水质受到土地利用、水系结构、经济发展等因素的综合影响. 土地利用变化 对于城市河流水质变化的影响虽弱于点源污染, 但却在一定程度上反映该区域人类活动扩张程度及空间布 局, 对于污染排放具有一定表征意义. 综合考虑土地利用结构、污染负荷以及土地利用格局变化导致的水质 指标变化, 对于水质变化趋势具有一定的解释意义.

\section{2 景观格局与河流水质}

综合两期分析结果, CONTAG 是水质的重要预测因子, 在 $1000 \mathrm{~m}$ 缓冲区对 $\mathrm{TP} 、 \mathrm{NH}_{3}-\mathrm{N} 、 \mathrm{TN}$ 等污染指标 呈现显著正相关. 张大伟等 ${ }^{[5]}$ 的研究也发现 CONTAG 与 TP 呈显著正相关,并解释为 CONTAG 值越大, 斑块 的聚集和连通越明显, 且景观中存在着优势斑块, 即城镇用地和旱地/水田优势斑块的聚集和良好联通关系 导致污染物集中产生与输出, 对河流水质的影响较显著 ${ }^{[5]}$; 吉冬青等 ${ }^{[20]}$ 及王瑛等 ${ }^{[30]}$ 则发现 CONTAG 与污染 指标呈现显著负相关. 产生不同结果可能与研究区主要景观类型有关, 如负相关区域以林地、耕地景观类型 为主, 正相关区域则以城镇用地、旱地、水田为主.

LPI 在 $1000 \mathrm{~m}$ 半径缓冲区与 $\mathrm{DO}$ 呈现较强的负相关关系, 与 $\mathrm{COD}_{\mathrm{Mn}} 、 \mathrm{NH}_{3}-\mathrm{N} 、 \mathrm{TN}$ 呈现较强的正相关关 系, 此时在各缓冲区内最大面积斑块是城镇用地或旱地, 其面积比例越大, 分布越集中, 造成污染物集中产 生和输出, 对水质具有明显的负面影响 ${ }^{[16]}$. 黄金良等 ${ }^{[4]}$ 与吉冬青等 ${ }^{[20]}$ 研究得出的结论则相反, 这主要与研 究区中的最大斑块类型有关.

SHEI 在 $1000 \mathrm{~m}$ 缓冲区与 $\mathrm{COD}_{\mathrm{Mn}} 、 \mathrm{NH}_{3}-\mathrm{N} 、 \mathrm{TN} 、 \mathrm{TP}$ 等污染指标呈显著负相关, 也是重要的水质预测因子. 与陈德超等 ${ }^{[16]}$ 在胥江流域的研究结果相似. 表明 SHEI 的值越大, 水体污染程度相对较轻. 究其原因, SHEI 反映了景观内斑块的均匀程度, SHEI 值越大, 各土地类型在面积和数量上的分布越均匀, 主要污染物产生输 出用地的优势程度和集中程度越不突出, 则污染物的产生和输出也相对分散, 因此对水质的影响相对缓 和 ${ }^{[16]}$. SHDI 与 TN 的负相关关系说明区域景观多样性对河流氮营养盐的产生具有一定缓解作用.

CONTAG 及 LPI 可表征景观斑块聚集程度及优势景观类型,SHDI 及 SHEI 可反映景观中各斑块类型的 丰富度, 是景观破碎程度的表征 ${ }^{[20]}$. 综合两期相关分析结果, 景观聚集程度与水质污染指标呈现正相关关 系, 破碎度则与之呈现负相关. 对比之前研究结果 ${ }^{[4-5,16,20,30]}$, 这与研究区域的优势土地利用类型及其特性具 有密切的关系.

综合已有研究结论及本文结果, 景观空间特征与水质间关系具有不确定性, 但景观空间属性对水质存 在较为明显的影响这一观点已得到普遍认同 ${ }^{[20]}$. 因此, 合理配置景观格局能够有效地治理面源污染, 改善 水质状况.

\section{5 结论}

本研究分析了 2004-2014 年苏州市水质变化情况,并以 7 条骨干河道为研究对象,结合空间缓冲区分 析与相关分析, 研究缓冲区景观格局对水质的影响及其变化特征. 结果表明:

2004-2014 年苏州市水质状况总体较差, 但呈现一定的好转趋势, 其中 $\mathrm{TN} 、 \mathrm{NH}_{3}-\mathrm{N}$ 是主要污染物。

综合两期相关分析结果, 研究区水质与城镇用地、水田、旱地密切相关, 反映了土地利用格局对水质的 复杂影响机制. 城镇用地、水田、旱地在不同缓冲区尺度分别与各水质指标呈现显著的相关关系, 并存在明 显的尺度相关性. 随着缓冲区尺度的增加, 土地利用类型与水质指标的相关性总体呈现增强的趋势, 在 700 
$1000 \mathrm{~m}$ 缓冲区范围内更为显著. 景观指数与水质指标的相关程度在大范围缓冲区相较于小范围缓冲区也更 为显著.

\section{6 参考文献}

[ 1 ] Guan Baohong, Li Jun, Zeng Aibin et al. Impacts of urban land use on water quality in Hangzhou. Resources Science, 2008, 30(6) : 857-863. [官宝红, 李君, 曾爱斌等. 杭州市城市土地利用对河流水质的影响. 资源科学, 2008, 30 (6): 857-863.]

[ 2 ] Zheng Jing, Fang Weihua, Shi Peijun et al. Modeling the impacts of land use change on hydrological processes in fast urbanizing region-A case study of the Buji watershed in Shenzhen City, China. Journal of Natural Resources, 2009,24 (9) : 1560-1572. [郑璟, 方伟华, 史培军等. 快速城市化地区土地利用变化对流域水文过程影响的模拟研究—— 以深圳市布吉河流域为例. 自然资源学报, 2009, 24(9) : 1560-1572.]

[ 3 ] Shao Yulong, Xu Youpeng, Ma Shuangshuang. Change of river structure and stream network connectivity in the Taihu Lake basin under the urbanization development-A case study in urban Suzhou. Resources and Environment in the Yangtze Ba$\sin , 2012,21(10):$ 1167-1172. [邵玉龙, 许有鹏, 马爽爽. 太湖流域城市化发展下水系结构与河网连通变化分 析一以苏州市中心区为例. 长江流域资源与环境, 2012, 21(10): 1167-1172.]

[ 4 ] Huang Jinliang, Li Qingsheng, Hong Huasheng et al. Preliminary study on linking land use \& landscape pattern and water quality in the Jiulong River watershed. Environmental Science, 2011, 32(1) : 64-72. [黄金良, 李青生, 洪华生等. 九龙 江流域土地利用/景观格局-水质的初步关联分析. 环境科学, 2011, 32(1): 64-72.]

[ 5 ] Zhang Dawei, Li Yangfan, Sun Xiang et al. Relationship between landscape pattern and river water quality in Wujingang region, Taihu Lake watershed. Environmental Science, 2010, 31(8): 1775-1783. [张大伟, 李杨帆, 孙翔等. 人太湖河 流武进港的区域景观格局与河流水质相关性分析. 环境科学, 2010, 31(8)：1775-1783.]

[ 6 ] Yue Juan, Wang Yanglin, Li Zhengguo et al. Spatial-temporal trends of water quality and its influence by land use: A case study of the main rivers in Shenzhen. Advances in Water Science, 2006, 17(3) : 359-364. [岳隽, 王仰麟, 李正国等. 河 流水质时空变化及其受土地利用影响的研究——以深圳市主要河流为例. 水科学进展, 2006, 17(3) : 359-364.]

[ 7 ] Fisher DS, Steiner JL, Endale DM et al. The relationship of land use practices to surface water quality in the Upper Oconee Watershed of Georgia. Forest Ecology and Management, 2000, 128(1) : 39-48.

[ 8 ] Tang Z, Engel BA, Pijanowski BC et al. Forecasting land use change and its environmental impact at a watershed scale. Journal of Environmental Management, $2005,76(1)$ : 35-45.

[ 9 ] Aheam DS, Sheibley RW, Dahlgren RA. Land use and land cover influence on water quality in the last free-flowing river draining the western Sierra Nevada, California. Journal of Hydrology, 2005, 313(3/4) : 234-247.

[10] Xia Rui, Li Yunmei, Wang Qiao et al. Response relationship between canal water quality and land-use using space statistical modeling. Journal of Natural Resources, 2011,(3): 364-372. [夏㕡, 李云梅, 王桥等. 京杭大运河无锡段水质和 土地利用的响应关系. 自然资源学报, 2011,(3) : 364-372.]

[11] Basnyat P, Teeter LD, Flynn KM et al. Relationships between landscape characteristics and nonpoint source pollution input to coastal estuaries. Environmental Management, 1999, 23(4) : 539-549.

[12] Zhang Yinjun, Chen Shuang, Peng Lihua. Relationships between land use pattern and surface water quality in the plain river network area: A case study of Wujiang in Jiangsu Province. Resources Science, 2009, 31(12): 2150-2156. [张殷 俊, 陈爽, 彭立华. 平原河网地区水质与土地利用格局关系一一以江苏吴江为例. 资源科学, 2009, 31 (12): 2150-2156. ]

[13] Tong STY, Chen W. Modeling the relationship between land use and surface water quality. Journal of Environmental Management, 2002, 66(4) : 377-393.

[14] Alberti M, Booth D, Hill K et al. The impact of urban patterns on aquatic ecosystems: An empirical analysis in Puget lowland sub-basins. Landscape and Urban Planning, 2007, 80(4) : 345-361.

[15] TU J. Spatially varying relationships between land use and water quality across an urbanization gradient explored by geographically weighted regression. Applied Geography, 2011, 31(1) : 376-392.

[16] Chen Dechao, Du Jinglong, Li Xin et al. A study on land use change and water quality response of Xujiang drainage basin. Urban Development Studies, 2013, 20(1):60-66. [陈德超, 杜景龙, 李新等. 胥江流域土地利用变化及其水质响应 
研究. 城市发展研究, 2013, 20(1):60-66.]

[17] Suzhou Bureau of Statics ed. Suzhou Statistical yearbook. Beijing: China Statistics Press, 2015. [苏州市统计局. 苏州统 计年鉴. 北京: 中国统计出版社, 2015.]

[18] Zhao Jun, Yang Kai, Tai Jun. Threshold and scaling effect of impervious surface impact on stream water quality in city with river networks. Journal of Hydraulic Engineering, 2012, 43(2): 136-142. [ 赵军, 杨凯, 邰俊. 河网城市不透水面的 河流水质响应阈值与尺度效应研究. 水利学报, 2012, 43(2) : 136-142.]

[19] King RS, Baker ME, Whigham DF et al. Spatial considerations for linking watershed land cover to ecological indicators in streams. Ecological Applications, 2005, 15(1) : 137-153.

[20] Ji Dongqing, Wen Ya, Wei Jianbing et al. Relationships between landscape spatial characteristics and surface water quality in the Liuxi River watershed. Acta Ecologica Sinica, 2015, 35(2) : 246-253. [吉冬青, 文雅, 魏建兵等. 流溪河流域 景观空间特征与河流水质的关联分析. 生态学报, 2015, 35(2): 246-253.]

[21] Yin Hailong, Xu Zuxin. Comparative study on typical river comprehensive water quality assessment methods. Resources and Environment in the Yangtze Basin, 2008, 17(5): 729-733. [尹海龙, 徐祖信. 河流综合水质评价方法比较研究. 长江 流域资源与环境, 2008, 17(5): 729-733.]

[22] Li Cuimei, Zhang Shaoguang, Yao Wenping et al. A bibliometrics analysis of status and trend of international research on field nitrogen application effects on nitrogen losses and water quality. Research of Soil and Water Conservation, 2016, 23 (3) : 354-359. [李翠梅, 张绍广, 姚文平等. 太湖流域苏州片区农业面源污染负荷研究. 水土保持研究, 2016, 23 (3) : 354-359. $]$

[23] Xing Guangxi. Containing nitrogen and phosphorus: Rural pollution source is difficulty. Environment Protection, 2007, (14)：49-50. [邢光喜. 遏制氮磷: 农村污染源是难点. 环境保护, 2007, (14)：49-50.]

[24] Jiang Deming, Jiang Wei. A simulative comparison of two kinds of transfer matrix methods for calculating Rayleigh wave curves. Geophysical and Geochemical Exploration, 2008, 32(4): 417-420. [蒋德明, 蒋玮. 国内外城市雨水径流水质 的研究. 物探与化探, 2008, 32(4): 417-420.]

[25] Feng Xiaojing, Jin Ke, Liang Zhongmin. Research on benefit evaluation of Yangtze River water transfer project. Water Resources and Power, 2012, 30(6): 135-138. [冯晓晶, 金科, 梁忠民. 引江济太工程调水效益评估. 水电能源科学, $2012, \mathbf{3 0}(6): 135-138$. ]

[26] Zhang Yihui. The study of land use change and its response relationship with water quality in riparian of Huangpu River [Dissertation]. Shanghai: East China Normal University, 2015. [张以晖. 黄浦江河岸带土地利用变迁及其水质响应 关系研究 [学位论文].上海: 华东师范大学, 2015.]

[27] Jung JW, Lee SW, Hwang HS et al. The effects of spatial variability of land-use on stream water quality in a costal watershed. Paddy and Water Environment, 2008, 6(3) : 275-284.

[28] Zhang Yinjun, Chen Shuang, Xiang Jingchang. Correlation between the water quality and land use composition in the river side area-A case of Chaohu Lake basin in China. Resources and Environment in the Yangtze Basin, 2011, 20(9) : 10541061. [张殷俊, 陈爽, 相景昌. 河流近域土地利用格局与水质相关性分析一一巢湖流域为例. 长江流域资源与 环境, 2011, 20(9) : 1054-1061.]

[29] Gao Chao, Zhang Taolin. Phosphorus sorption and desorption of upland soils in the hilly areas of Taihu Lake watershed. $J$ Lake Sci, 2001, 13(3) : 255-260. DOI: 10.18307/2001.0309. [高超, 张桃林. 太湖地区丘陵旱地土壤磷的吸持解吸 特征. 湖泊科学, $2001, \mathbf{1 3}(3): 255-260$.]

[30] Wang Ying, Zhang Jianfeng, Chen Guangcai et al. Responses of water quality to landscape pattern in Taihu watershed: Case study of 3 typical streams in Yixing. Acta Ecologica Sinica, 2012, 32(20): 6422-6430. [王瑛, 张建锋, 陈光才 等. 太湖流域典型人湖港口景观格局对河流水质的影响. 生态学报, 2012, 32(20)：6422-6430.] 